\title{
Stage D Prostate Cancer
}

National Cancer Institute

\section{Source}

National Cancer Institute. Stage D Prostate Cancer. NCI Thesaurus. Code C7099.

Metastatic disease. -- 2004 